AWEJ for Translation \& Literary Studies, Volume3, Number4. October 2019

DOI: http://dx.doi.org/10.24093/awejtls/vol3no4.5

Pp. $46-60$

\title{
The Effects of the Use of Google Translate on Translation Students' Learning Outcomes
}

\author{
Reem Alsalem \\ Department of English Language and Translation \\ College of Languages and Translation, King Saud University, \\ Riyadh, Saudi Arabia
}

\begin{abstract}
This paper investigates the effects of uncontrolled use of Google Translate (GT) on the development of students' translation skills. It aims to find out if the current patterns of GT use by translation students could impact their learning outcomes, and if so, in what ways. The study uses think-aloud data from actual translation efforts of four students. Analysis of the four subjects' translations show that their overreliance on GT for first drafts reduced their propensity to search for equivalents. However, when students post-edit poorly constructed GT sentences, they carry out a process of analysis and synthesis similar to the process of translating from scratch. The study concludes that post-editing GT translation is beneficial for translation students' development of translation skills, but it warns against introducing or allowing its use at the elementary stages of translation training.
\end{abstract}

Keywords: Google Translate, machine translation, post-editing, think-aloud, translation memory, translation skills, translation training

Cites as: Ethelb, H. (2019). Dialects on Screen: Translating Jordanian Dialect into English The Case of Captain Abu Raed Film. Arab World English Journal for Translation \& Literary Studies3 (4)46-60. DOI: http://dx.doi.org/10.24093/awejtls/vol3no4.5 